\title{
Entry Class and the Early Employment Experience of Immigrants in Canada
}

\author{
Kelli Phythian \\ Department of Sociology \\ University of Western Ontario \\ London, Ontario, Canada \\ E-mail: klphythi@uwo.ca \\ David Walters \\ University of Guelph \\ Guelph, Ontario, Canada \\ Paul Anisef \\ York University \\ North York, Ontario, Canada
}

\begin{abstract}
Despite its policy importance, research related to the economic performance of immigrants by entry class is sorely lacking. It is generally presumed that immigrants selected on the basis of human capital will have better economic outcomes than unscreened immigrants; however, there is speculation that the social networks of family immigrants provide access to employment resources not available to others. Both arguments have merit, yet there is little research to support either claim. This study utilizes data from the Longitudinal Survey of Immigrants to Canada to investigate the association between entry class and employment status of immigrants six months after arrival. Findings reveal little difference between skilled workers and family immigrants, while business immigrants and refugees are much less likely to be employed. Policy implications are discussed.
\end{abstract}

Keywords: Immigrants, employment, labour market outcomes, entry class 


\section{Résumé}

En dépit de son importance sur les politiques, la recherche sur la performance économique des immigrants selon leur classe d'entrée fait sérieusement défaut. Il est généralement présumé que les immigrants choisis pour leur capital humain auront une meilleure situation économique que ceux issus d'une immigration non-contrôlée ; il est aussi conjecturé que les réseaux sociaux des immigrants de regroupement familial offrent des possibilités de travail qui ne sont pas à la portée des autres immigrants. Les deux arguments ont du mérite, mais il existe peu de recherche pour valider l'une ou l'autre de ces propositions. Cet article s'appuie sur l'Enquête longitudinale auprès des immigrants du Canada pour examiner le lien entre la classe d'entrée et la situation professionnelle six mois après l'arrivée au pays. Les constatations de l'enquête révèlent peu de différence entre les travailleurs qualifiés et les immigrants de regroupement familial, bien que les gens d'affaires immigrants et les réfugiés aient beaucoup moins de chance d'avoir un emploi. Les implications au niveau des politiques sont discutées.

Mots clés: immigrants, emploi, résultat sur le marché du travail, classe d'entrée

\section{Introduction}

Since the revival of large scale immigration following World War II, the primary goal of Canadian immigration policy has been oscillating between fulfilling the economic needs of the country and facilitating family reunification. With these changing priorities came fluctuations in the composition of entry classes; in some years, as little as one-fifth of the inflow was admitted under the family class, while in others, more than one-half of immigrants were family members of Canadian residents (CIC 2005; Manpower and Immigration 1974a). Today, the pendulum is firmly planted in the economic domain. The main objective of Canada's immigration program is to create a more skilled and flexible workforce that better meets the demands of its changing economy (Green and Green 1999). Though kinship-based immigration remains an important component of the current immigration program, it has taken a backseat to contemporary economic goals. 
The issue of whether immigrant selection affects the labour market prospects of newcomers is an important political question. Between 1996 and 2007, 1.3 million economic migrants have been admitted to Canada in order to facilitate economic growth. However, deteriorating labour market outcomes among recent immigrants - including lower labour force participation, higher unemployment, and lower earnings (Picot, Hou, and Coulombe, 2007; Picot and Sweetman, 2005) - inevitably raise questions about the effectiveness of a skillselective immigration program designed to ensure that immigrants will rapidly integrate into the Canadian economy (Hiebert, 2006). Can Canada's current emphasis on economic migration, at the expense of family reunification, be justified on the basis of more rapid economic integration? More specifically, do immigrants admitted under the economic class outperform those admitted as part of the family class and refugee programs?

The purpose of the present study is to test the assumption that immigrants screened for skills and experience have better labour market outcomes than unscreened immigrants. Previous research has revealed that there are indeed differences across entry classes, yet this research has tended to focus on earnings (DeVoretz, Pivnenko and Beiser, 2004; Wanner, 2003; De Silva 1997). This picture, however, is incomplete. On their own, wage differentials are not proof of disparate labour market outcomes. By definition, the emphasis on earnings includes only those who are employed and hence overlooks all of those who are in the labour force but out of work. As such, evidence of wage differences across entry classes may be theoretically and politically misleading should there be differences in the unemployment rate across entry classes, particularly if those classes who average higher wages tend also to have high rates of unemployment. To help build a more comprehensive understanding of the labour market position of immigrants across entry classes, this study focuses specifically on the employment status of immigrants upon arrival.

\section{Review of Literature}

The current federal government headed by Stephen Harper has been explicit in its belief that skilled immigration is necessary for sustained economic growth in Canada. In his recent speech to the Canada-India Foundation concerning the application processing backlog, Harper stated that,

In the next five years, Canada's labour force growth, without enhanced immigration, will simply cease.... Not only is the backlog a source of great irritation for those patiently waiting their term, it will hold back Canada's economic growth. Many skilled immigrants are already giving Canada a pass and moving instead to countries like Australia and New Zealand 
where the wait is measured in months, not years. Many of those waiting have the skills, education and work experience needed by the Canadian economy this very moment.... [Our] government is determined to take action and get people flowing through the system and into the Canadian workforce where we need them right now (April, 2008).

This commitment to economic growth through immigration is manifested in the entry class composition of newcomers. At present, there are five entrance categories under which potential immigrants can apply: skilled workers, business immigrants, the Canadian experience class, the family class, and refugees. Between 1996 and 2007, the economic classes together made up 58 percent of all entrants, whereas family immigrants constituted less than one-half of this, at just 28 percent of the total inflow (CIC Facts and Figures, 2008). This is complete reversal from the earlier immigration trends; in 1983, the family class comprised 55 percent of all newcomers and economic migrants represented 27 percent of persons who were admitted.

The economic priorities of Canada's current immigration policy are also reflected in the eligibility requirements for the three classes. Like many countries of immigration, selection criteria and target levels are determined, and even justified, by the benefits that 'quality' immigrants are thought to bring to the economy. In Canada, quality is judged on the basis of human capital; eligibility requirements for skilled worker applicants include high levels of education and work experience, skills relevant for work in preferred occupations, and knowledge of a charter language. Depending on the category under which they apply, business class applicants are required to demonstrate a minimum net worth of $\$ 300,000$ to $\$ 800,000$ or they must meet minimum human capital requirements. Immigrants with immediate family members already living in Canada need not meet specific skills or financial criteria, but they are required to have a sponsor (typically the family member) who has agreed to provide financial support for a period of three to ten years following arrival. Skilled workers require no such support, and they need only demonstrate that they are able to provide for themselves and their dependents during the first six months of settlement.

Building a more highly skilled workforce through immigration is paired with the second goal of minimizing the cost of immigration to the public purse (Green and Green 1999). The extensive sponsorship criterion for family class applicants combined with the comparatively few financial resources required of skilled worker applicants implicitly suggests that unscreened immigrants are more likely to experience difficulties in the labour market. Thus, by placing financial responsibility on the shoulders of sponsors, the cost of admitting (presumably) low- and unskilled workers through the family class is thought to be reduced. Interestingly, overlooked in this scenario is the vital role that 
sponsored immigrants have played in Canada's history. Following World War II, sponsored immigrants contributed to the Canadian labour market in important ways. They helped meet persistent demands for factory, railway, construction, and agricultural workers, and they tended to settle in more quickly than their unsponsored counterparts as a result of their ready-made social networks (Manpower and Immigration 1974b:22; Hawkins 1972:50).

Of course, the Canadian economy is no longer booming with lucrative opportunities for anyone willing to work. The emergence of a knowledge economy has brought an increase in the relative importance of professional, managerial, and information technology-type jobs that typically require some level of post-secondary skills training (Drucker 1993; Stehr 1994). As these jobs become more critical to the economy, those who fill them are more highly rewarded. Low-skill manufacturing jobs, which once permitted newcomers access to the mainstream economy because they lacked specific skill and language requirements, comprise a decreasing share of Canada's labour market and typically pay low wages and offer few opportunities for upward mobility (Krahn and Lowe, 1998; Zhou, 1997). Between 1970 and 2006, for instance, the share of jobs in manufacturing declined by 9.1 percentage points (Pilat et al., 2006). In response to the loss of 52,000 manufacturing jobs between January and April, 2007, Ken Georgetti, president of the Canadian Labour Congress, recently claimed that "Canada's manufacturing sector is in crisis. We're losing our best paying and highly skilled jobs at a rate that should have the alarm bells ringing" (2007:1). The new knowledge economy has increased the demand for highly skilled workers and has reinforced the belief that highly selective admission criteria are needed to ensure that immigrants are able integrate into their new economy.

Researchers and policy makers alike have generally taken for granted that immigrants selected on the basis of education, skills, and labour market demands will be more successful in the local labour market than family immigrants (see, for example De Silva, 1997; Jasso and Rozenzweig 1995; Wright and Maxim 1993). Yet, despite a strong preference for immigrants who meet specific human capital criteria, there is very little evidence to suggest that those from the skilled worker and business classes have better employment outcomes than those admitted under the family class. The scant literature in this area indicates that immigrants who are admitted under the points system and the business class have higher earnings upon arrival than family class migrants and refugees (Wanner 2003; De Silva 1997). In spite of this, their earnings were found to have converged well within the span of a working life. Chiswick (1978) suggests that differences in the rates of earnings growth among sponsored relatives and economic immigrants can be explained by differences in human capital investment in the host country. Economic immigrants, he argues, already possess the skills necessary for high demand occupations in the host society, which accounts for their greater earnings at entry. Family class 
immigrants, on the other hand, have social networks in place upon arrival, which make further investments in human capital more likely (see also, Duleep and Regets 1996; Jasso and Rosenzweig 1995). As the labour market changes over time, those who have locally obtained language and skills training will have a stronger foothold in the economy and will experience more rapid earnings growth as a result.

Though research findings demonstrate that family class immigrants tend to perform less well at entry than economic immigrants, the focus on earnings is incomplete. Lower earnings at entry is not a sure sign of poorer labour market performance, as indicated by longitudinal findings demonstrating that family class immigrants have an impressive capacity to catch up to those admitted on the basis of education credentials and work experience. Further, the focus on earnings, and hence only those who are employed, neglects all persons who are in the labour force but who are out of work. If there are substantial differences in the unemployment rate across entry classes, findings from analyses of those who are working at the time of survey are likely to be misleading. For instance, skilled workers may have a stronger tendency to delay employment until they find jobs that are commensurate with their skills and training; this group might therefore simultaneously exhibit higher unemployment and higher earnings compared to those belonging to other entry classes. Thus, it is difficult to draw conclusions about the relative economic position of immigrants across entry classes without knowledge of employment status to compliment findings related to immigrant earnings.

Whether newcomers are able to find work is important for many reasons, not the least of which has to do with the "cost" of immigration. Immigrant participation in government transfer programs, such as employment insurance (EI) and welfare, has long been a contentious issue for taxpayers and policy makers and the concern may be justified. Census data show that, throughout the 1990 s, unemployment rates for recent immigrants with a university degree were at least three times that of the native-born (Galarneau and Morissette 2005). High unemployment means a more costly social safety net as EI and welfare claims are paid out to a greater number of people. The composition of immigrants by entry class might play some role in determining the overall size of welfare and EI payouts. If there is variation across entry classes in terms of unemployment rates and hence the likelihood of welfare use, the allocation of tax dollars to these programs will depend in part on the proportion of immigrants entering under each class.

Using data from the Longitudinal Immigration Data Base, Marr and Siklos (1999) reported substantial differences across entry classes in the percentage of claims made against Canada's unemployment program (UI). Looking at immigrants who arrived in 1980, 1985, and 1989, the authors found that, for all cohorts and for both men and women, skilled workers were least likely to make UI claims, followed by family class immigrants and refugees, 
though the differences narrowed over time. The authors go on to conclude that their findings support claims that skilled workers should constitute a greater proportion of the total annual inflow. As the authors acknowledge, however, there were two severe recessions during the study period (1980 to 1995). Economic recessions affect workers in different ways. Unskilled workers and recent immigrants are especially vulnerable: they are subject to a much higher risk of unemployment and welfare costs for these groups are thus considerably larger (Mukoyama and Sahin 2006; McDonald and Worswick 1998; 1997). To make matters worse, job creation following the recessions took place almost exclusively within the service sector, and high turnover rates in manufacturing occurred as a result of major restructuring (Crompton and Vickers 2000). Consequently, the recessions and the reorganization of the labour force that ensued likely had differential effects across immigrant groups, with low- and unskilled immigrants admitted under the family and refugee classes having been hit particularly hard. Further research on the employment experience of newcomers is therefore needed to confirm whether the unemployment experience of newcomers indeed varies across entry class, or if previous findings can be attributed to the turbulent economy of the 1980s and 90s.

The issue of whether immigrant selection affects the labour market prospects of newcomers is an important one. Canadians take pride in and jealously guard their social welfare system; when it is believed that outsiders are taking advantage of their generosity, hostility quickly builds. The composition of immigrants is intended to weed out those who may be unable to support themselves upon arrival and hence minimize the number of new entrants that will pose a burden to the state. Yet the highly selective admission criteria, intended to admit first and foremost the well educated and the highly skilled, have not improved the at-entry labour market position of recent immigrant cohorts. Between the late 1960s and early 1990s, the entry wages of Canadian immigrants have declined with each successive cohort and their low-income rate has been continuously rising, even as that of the Canadian-born has declined (Picot and Sweetman 2005; Aydemir and Skuterud 2005; Worswick 2003; Frenette and Morrisette 2003; Li 2003; Waslander 2003; Reitz 2001; Bloom, Grenier, and Gunderson 1995; Baker and Benjamin 1994).

Given recent trends related to the deterioration of immigrant labour market outcomes, questions arise concerning the effectiveness of an immigration program that is based on the assumption that rapid and successful economic integration will occur only if the best and the brightest are admitted. Though economic immigrants have the advantage of higher levels of education and work experience, family class migrants are afforded the benefit of having a social network in place upon arrival. In addition, family applicants are required to have a sponsor in order to gain entry. The presence of a social network, along with potential pressures faced by family-class immigrants to find employment in 
order to minimize the period during which they are dependent on their sponsor, may serve to accelerate entry into the labour market.

Despite its policy importance, little is known about the association between entry class and immigrant labour market outcomes. This is due mainly to a lack of available data. Most research related to the economic performance of immigrants has made use of census data, but foreign-born respondents are not asked the class under which they were admitted. As stated above, the presumption is that immigrants screened on the basis of skills will perform better in the labour market than those selected because they have kinship ties to persons already living in Canada. The purpose of the present study is to test this assumption. We also investigate the relationship between human capital and employment status to determine whether screening for human capital is indeed an effective means for maximizing the economic potential of immigrants. The human capital model, upon which immigrant selection criteria are based, predicts that immigrants admitted as skilled workers will have a greater probability of being employed than family class immigrants and refugees, as will those with higher levels of education and with greater English or French language proficiency. The social capital hypothesis, on the other hand, predicts that family class immigrants benefit from the social ties that are in place upon arrival. We expect to find little difference between economic and family class immigrants in terms of the probability of finding employment at entry, as the former will benefit from their skills and experience and the latter will benefit from pre-existing social networks.

Given previous research findings indicating that the labour market earnings of family class immigrants and refugees quickly catch up to those of skilled workers, one might also expect that differences in employment rates of immigrants across entry classes also converge with time. In order to capture differences in economic performance before convergence occurs, it is necessary to measure employment status early in the settlement process. Thus, the dependent variable for this study is employment status six months after arrival.

\section{Methods}

This study uses data from the first wave of the Longitudinal Survey of Immigrants to Canada (LSIC) made available through Statistics Canada's Research Data Centres. The LSIC contains extensive information related to the sociodemographic, education, and employment characteristics of new immigrants to Canada. The sample of 20,322 immigrants was drawn from all permanent residents admitted to Canada from abroad between 01 October 2000 and 30 September 2001. The LSIC is therefore a valuable resource for investigating the at entry labour market performance of a single immigrant cohort that arrived in Canada at roughly the same time. Because the focus of the 
present study is on employment status, this analysis includes only respondents of primary working-age (i.e., between 24 and 49 years) who indicated an intention to find employment while living in Canada. Respondents who were in school full-time at the time of the interview were excluded, as were those who were not in the labour force. Findings are based on a subsample of 6,548 immigrants from the first wave of the LSIC, which was conducted six months after the arrival of each respondent.

We use logistic regression to model the probability of being employed as a function of immigrant entry status, while controlling for differences in human capital and demographic characteristics. Logistic regression is a multivariate technique that allows one to predict a discrete outcome, such as employment status, from a set of continuous, discrete, or dichotomous variables (for a more technical discussion, see McCullagh and Nelder 1989). The dependent variable in this analysis is employment status (employed versus unemployed) at the time of the survey. The key independent variable, entry class, distinguishes between immigrants admitted under the following categories: family class, skilled workers, business class, and refugees (including both government and other refugees). Among immigrants classified in the skilled worker category, we distinguish between those who immigrated as principal applicants and those who immigrated as spouses or dependents. ${ }^{1}$

Sociodemographic characteristics, including age, sex, marital status, ethnicity, the presence of dependent children, and region of residence are controlled. Measures of human capital are also included in order to determine the extent to which educational attainment and language proficiency impact the likelihood of being employed. Education is measured using two variables: the highest level of schooling obtained before arriving in Canada and the region in which educational credentials were obtained. In terms of language proficiency, LSIC respondents were asked to report their level of competence in both English and French. The variables were combined and recoded to distinguish between those respondents who speak English or French very well and those who speak neither English nor French very well. Further descriptions of the variables used in the analysis, including means and frequencies, are provided in Table $1 .^{2}$

\section{Results}

Among the immigrant entry classes, principal applicants admitted to Canada as skilled workers account for 48 percent of the respondents in the working sample, while spouses and dependents of skilled workers constitute another 27 percent of respondents. Family class immigrants make up 16 percent of the sample, and business immigrants and refugees compose another four and five percent of the sample, respectively. These values differ somewhat from official immigration statistics due to the nature of the working sample (i.e., only persons aged 24 to 
49 who intend to work while living in Canada). According to Citizenship and Immigration Canada (Facts and Figures, 2007), 49 percent of immigrants aged 15 and older who arrived in 2000/2001 and who intended to work were part of the economic class (i.e., skilled workers and the business class), while another 16 percent were their spouses and dependents. Twenty-three percent were family class applicants and 11 percent were refugees.

Preliminary analyses indicate that approximately 55 percent of the overall sample is employed and 45 percent is unemployed. Of those who are employed, 81 percent reported having found full-time work, while only 19 percent work part-time. In absolute terms, this translates into 774 respondents. Because of the relatively small sub-sample of part-time workers, separate analysis of this group was not possible. Thus, full-time and part-time workers were combined to create two categories: employed versus unemployed. Descriptive analyses (not shown) indicate that there is some variation across entry classes in the proportion of respondents who work full-time versus those who work part-time, but the differences are small. For immigrants of all entry classes, the probability of having full-time work far exceeded the probability of working part-time.

Roughly 55 percent of the sample is male and 45 percent is female. An overwhelming proportion of the immigrants are married ( 84 percent), while 14 percent are single, and 2 percent are divorced, separated, or widowed. In terms of ethnicity, 36 percent of the respondents in the working sample are Asian, 25 percent are South Asian, 21 percent are White, 5 percent are Black, and 12 percent are classified as "other." Roughly one half of respondents have dependent children, and the majority resides in Ontario (62 percent). More than 70 percent of the survey respondents have a university degree or above, and only a small proportion of have obtained their highest level of education in the United States (four percent) or Europe, Australia or New Zealand (seven percent). With respect to language proficiency, slightly less than one-half of the immigrants in this study report that they can speak either English or French very well. Finally, the mean age in our sample is 34 years.

Logistic regression estimates are displayed in Table 2. Model 1 provides estimates for the entry class variable. These estimates represent the log of the odds of being employed versus being unemployed. The parameter estimates obtained from this model reveal significant differences in employment status across the five entry classes $(\mathrm{p}<.001)$. These estimates were converted into predicted probabilities and plotted in Figure 1. The fitted probabilities are also accompanied by corresponding 95\% confidence intervals. Figure 1(a) represents the probability of being employed for each of the five entry classes. The fitted values indicate a markedly wide range in the predicted probability of being employed by entry status. Principal applicant skilled workers are most likely to have attained employment (.67), followed very closely by immigrants in the family class (.61). The difference, though statistically significant, is small. Notably, family class immigrants are considerably more like to report 
Table 1

Descriptive Statistics for Study Variables $(n=6548)$

\begin{tabular}{|c|c|}
\hline Variables & Mean/Proportion \\
\hline $\begin{array}{l}\text { Entry Class } \\
\text { Skilled Workers (principal applicant) } \\
\text { Skilled Workers (spouse and dependent) } \\
\text { Business Immigrants } \\
\text { Refugees } \\
\text { Family Class }\end{array}$ & $\begin{array}{l}0.48 \\
0.27 \\
0.04 \\
0.05 \\
0.16\end{array}$ \\
\hline Sociodemographic Variables & \\
\hline $\begin{array}{l}\text { Sex } \\
\quad \text { Female } \\
\text { Male }\end{array}$ & $\begin{array}{l}0.45 \\
0.55\end{array}$ \\
\hline $\begin{array}{l}\text { Marital Status } \\
\text { Previously Married } \\
\text { Single } \\
\text { Married/Common Law }\end{array}$ & $\begin{array}{l}0.02 \\
0.14 \\
0.84\end{array}$ \\
\hline $\begin{array}{l}\text { Ethnic Status } \\
\text { South Asian } \\
\text { Black } \\
\text { Asian } \\
\text { Other } \\
\text { White }\end{array}$ & $\begin{array}{l}0.25 \\
0.05 \\
0.36 \\
0.12\end{array}$ \\
\hline $\begin{array}{l}\text { Dependent Children } \\
\text { No } \\
\text { Yes }\end{array}$ & $\begin{array}{l}0.51 \\
0.49\end{array}$ \\
\hline Age & 34 \\
\hline $\begin{array}{l}\text { Region of Residence } \\
\text { Eastern Provinces } \\
\text { Quebec } \\
\text { Western Provinces } \\
\text { Ontario }\end{array}$ & $\begin{array}{l}0.01 \\
0.14 \\
0.13 \\
0.62\end{array}$ \\
\hline $\begin{array}{l}\text { Language } \\
\text { Does not speak English or French very well } \\
\text { Speaks English and French very well }\end{array}$ & $\begin{array}{l}0.52 \\
0.48\end{array}$ \\
\hline Human Capital & \\
\hline $\begin{array}{l}\text { Region of Schooling } \\
\text { Europe, Australia, New Zealand } \\
\text { Other } \\
\text { United States }\end{array}$ & $\begin{array}{l}0.07 \\
0.89 \\
0.04\end{array}$ \\
\hline $\begin{array}{l}\text { Highest Level of Schooling before Arrival } \\
\text { High School Diploma } \\
\text { Postsecondary Education (less than a BA) } \\
\text { University Degree } \\
\text { Advanced University Degree } \\
\text { Less than High School }\end{array}$ & $\begin{array}{l}0.08 \\
0.18 \\
0.46 \\
0.25 \\
0.04\end{array}$ \\
\hline $\begin{array}{l}\text { Employment Status } \\
\text { Employed } \\
\text { Unemployed }\end{array}$ & $\begin{array}{l}0.55 \\
0.45\end{array}$ \\
\hline
\end{tabular}


Table 2

Parameter Estimates from the Logistic Regression Model Predicting Employment from the Independent Variables: Canada

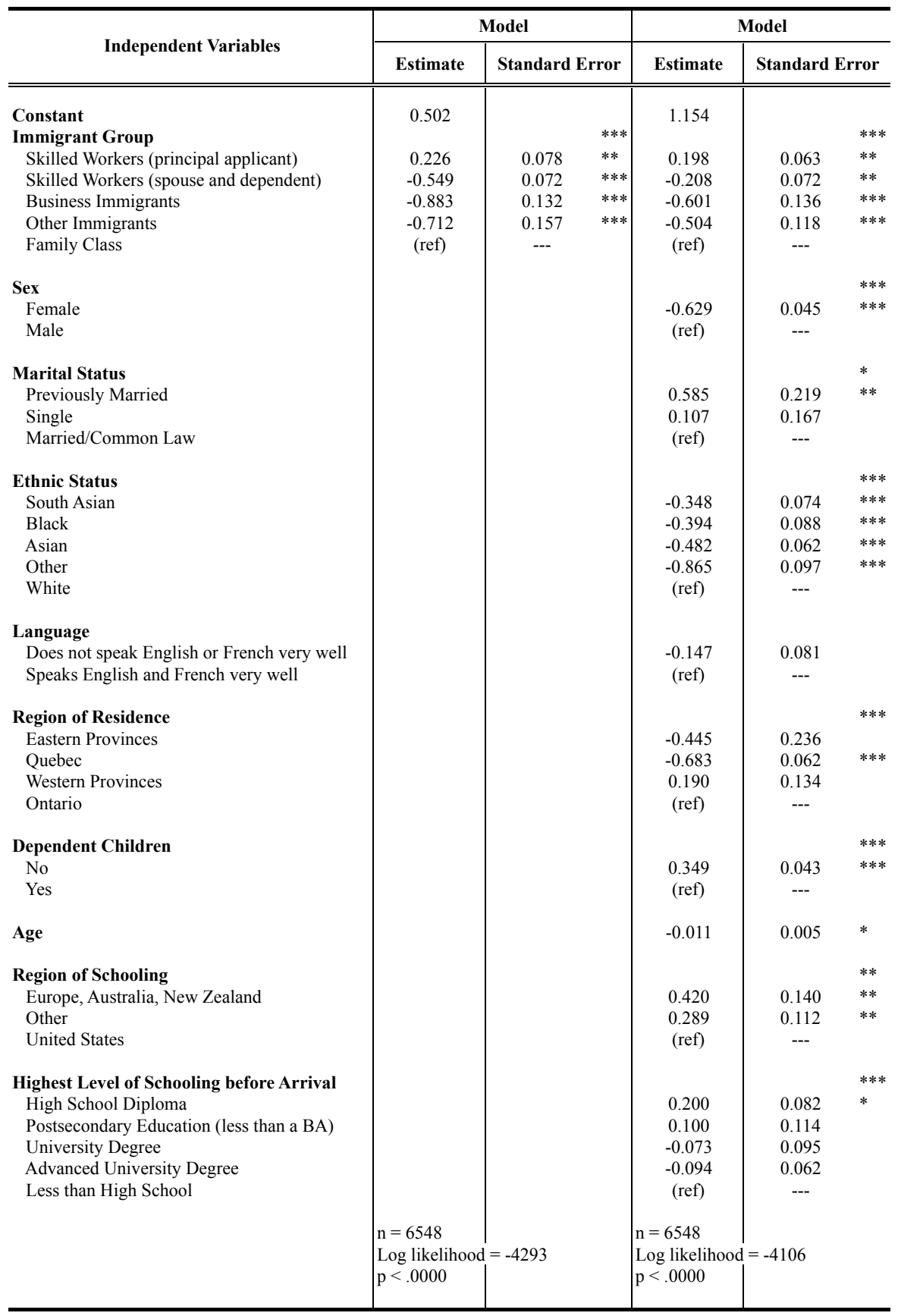

$*$ P-value $<.05 ; * *$ P-value $<.01 ; * * *$ P-value $<.001$ 
having found employment than the spouses and dependents of skilled workers (.49). Business class immigrants and refugees have the lowest probabilities of being employed. Their respective fitted probabilities are .40 and .45 .

The estimates in Model 2 add controls for demographic characteristics, language proficiency, and education. All of the independent variables have a significant impact on employment status, and most of the parameter estimates for these variables are consistent with expectations based on existing literature. One surprising finding is that immigrants from the United States appear to have a more difficult time securing employment upon arrival than immigrants from other parts of the world. Also unexpected is the finding that respondents with higher levels of schooling are less likely to be employed soon after arriving than less educated immigrants. This suggests that more highly educated immigrants take longer to find employment, perhaps because they are willing to wait for jobs that are commensurate with their skills and experience. Alternatively, the latter result may be due to greater competition with the native-born for highly skilled positions that require advanced degrees (see Reitz, 1998). More highly educated immigrants would therefore be forced to search harder and longer, and in some cases take time to upgrade their skills, if they hope to find employment that matches their credentials.

The entry status variable remains statistically significant after controls for human capital and demographic variables are added in Model $2(\mathrm{p}<.001)$. As with Model 1, the log-odds estimates were converted for the entry status variable into meaningful quantities and the respective fitted probabilities are plotted in Figure 1(b). The predicted probabilities and their corresponding confidence intervals are obtained while holding the control variables constant at typical values.

The fitted probabilities reveal a similar pattern in Figure 1(b) when the controls are added to the model. However, the fitted probabilities of being employed for all immigrant groups are higher, and the range of fitted values is considerably smaller in Figure 1(b) than in Figure 1(a). For instance, when holding the demographic, language, and the education variables constant at typical values, the fitted probabilities of employment range from .61 for business immigrants to .79 for principal applicant skilled workers. Thus, when comparing the two graphs in Figure 1, it appears that much of the disadvantage that business class immigrants and refugees experience in terms of securing employment in Canada shortly after arrival is attributable to differences in demographic characteristics, language, and education. Similarly, the employment advantage of skilled workers relative to the family class diminishes substantially. Though parameter estimates indicate that they remain significantly more likely to report having found work six months after arrival than family immigrants, the difference is marginal. 


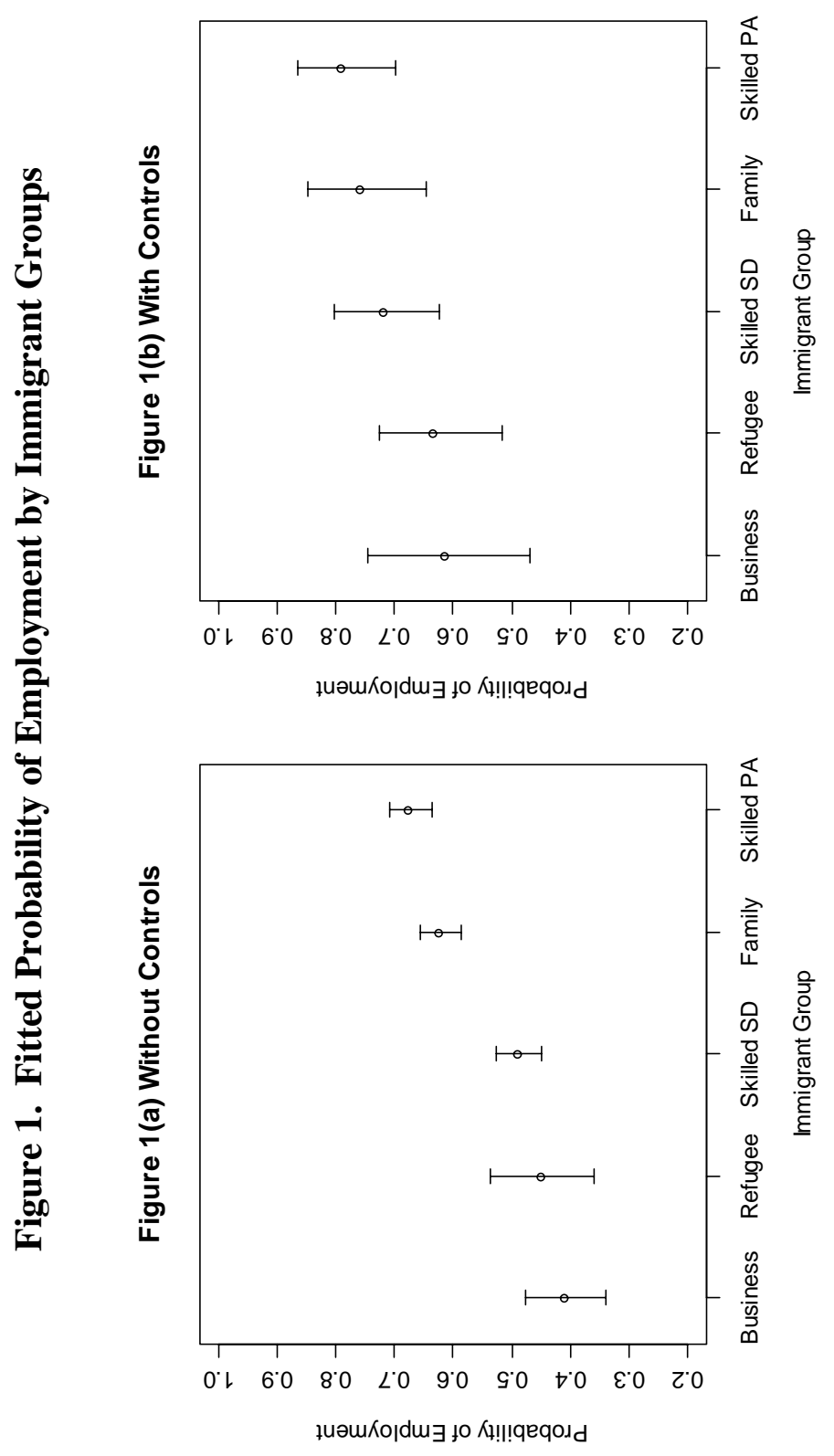




\section{Conclusion}

Despite its obvious policy importance, the presumption that immigrants screened on the basis of skills and experience will fare better in the labour market than those who are not screened has rarely been tested empirically. Existing literature concentrating on immigrant entry status and labour market performance is sparse and has focused exclusively on the earnings attainment of persons admitted under various entrance categories. This research has demonstrated that the average at entry earnings of screened applicants is higher than that for kinship-based immigrants and refugees. However, the wages of each group quickly converge due to more rapid earnings growth for those belonging to the latter two groups. This research is important in that it establishes that the long term outcomes of employed immigrants do not vary substantially by entry status, yet it fails to consider that immigrants from some groups may have more trouble finding employment than others. By ignoring the unemployed, disparities in labour market performance across immigrant groups may be under- or overestimated if there are differences in employment status by category of entry.

Using data from the Longitudinal Survey of Immigrants to Canada, we analyzed differences in employment status by entry class for a sample of immigrants who had arrived six months previous. The sample was restricted to immigrants aged 24 to 49 who reported an intention to work while living in Canada. As predicted, results revealed a small, though significant, difference in the employment status of skilled workers and family class immigrants six months after arrival. Further, these groups are considerably more likely to report having found employment than the spouses and dependents of skilled workers, business immigrants, and refugees. Much of the observed disparities in employment can be attributed to differences in demographic characteristics and human capital, which were included in Model 2. In other words, the probability of being employed would be similar for all entry classes if their demographic characteristics, educational backgrounds, and level of language proficiency were the same.

The marginal difference between skilled worker principal applicants and family class immigrants in the likelihood of being employed six months after arrival is particularly noteworthy. Despite not having been screened for human capital, this group is nearly equally likely as screened immigrants to find employment within the first six months of entry. These findings suggest that the presence of social capital in the form of a sponsor may indeed offset the human capital disadvantage that they have relative to skilled worker principal applicants. Of course, further research into the social networks of immigrants is necessary to support this conclusion. 
These findings, in addition to those of other researchers, suggest that an immigration program intended to ensure favourable employment outcomes of immigrants destined for the labour force need not restrict so heavily the proportion of immigrants entering under the family class. Though statistically significant, the difference in the rate of employment between skilled workers and family class immigrants headed for the labour force is marginal. Previous research also indicates rapid earnings convergence across entry classes (Wanner 2003; De Silva 1997). Taken together, the evidence indicates that immigrants who are not screened for skills and labour market suitability are able to attain economic success comparable to those who are screened, albeit with a slight lag. Thus, a rise in the proportion of family immigrants is unlikely to have much of an impact on the overall economic performance of immigrants in the labour market.

In sum, the findings of the present study indicate that the labour market disparities among various immigrant groups are established within a very short period after arrival. A central concern arising from this analysis is that one-third of recent economic immigrants are unemployed six months after moving to Canada. It may be ambitious to expect skilled worker immigrants to find employment within six months; to be sure, more highly skilled immigrants might await opportunities that are commensurate with their education and experience. Also interesting is the relatively low employment rate reported by business immigrants and refugees. Many business immigrants arrive in Canada with money in hand - indeed, they are required to have large sums of money to gain admission - and wait for the development of business opportunities. These immigrants are typically headed for self-employment; thus, low levels of employment (including self-employment) among this group can be expected. As for refugees, their unique situations, the provision of financial support from the state and from private sponsors, and perhaps an expectation to return to one's home country should the opportunity present itself, suggest that finding employment may not be a priority so soon after arrival.

The purpose of this research was to examine the employment outcomes of immigrants shortly after arriving in Canada. Future researchers might build on these findings by investigating the factors that influence labour market changes during the initial years of settlement. The final waves of the LSIC will be a valuable instrument for social researchers interested in examining the labour market trajectories of immigrants over time, including unemployment spells, welfare use, earnings growth, and poverty. To be sure, there is a crucial need for such research, given the growing importance of immigration to Canada as a tool for economic and population growth. 


\section{End Notes}

1. Family class immigrants are family members - usually spouses, conjugal partners, dependent children, parents, and grandparents - of Canadian citizens and permanent residents who are admitted on the basis of familial relationships and the promise that they will be supported financially for a predetermined period following arrival. The spouses and dependents of skilled workers, on the other hand, are the family members that accompany immigrants who are admitted under the points system.

2. Proportions are used for categorical variables and the mean is used for age.

\section{References}

Aydemir, A. and M. Skuterud. 2005. "Explaining the Deteriorating Entry Earnings of Canada's Cohorts: 1966-2000," Canadian Journal of Economics 38(2): 641-672.

Baker, M. and D. Benjamin. 1994. "The Performance of Immigrants in the Canadian Labour Market," Journal of Labour Economics, 12: 369-405.

Bloom, D. E., G. Grenier, and M. Gunderson. 1995. "The Changing Labour Market Positions of Canadian Immigrants," Canadian Journal of Economics 28: $987-$ 1005.

Canadian Labour Congress. May 11, 2007. "Manufacturing Job in Crisis: Canada's Economy Sheds over 50,000 Good Jobs Since January." Press Release. Retrieved November 7, 2007 (www.canadianlabour.ca).

Chiswick, B. R. 1978. "The Effect of Americanization on the Earnings of Foreign-born Men," The Journal of Political Economy 86(5): 897-921.

Citizenship and Immigration Canada (CIC). 2008. Facts and Figures Immigration Overview: Permanent and Temporary Residents. Ottawa: CIC.

Citizenship and Immigration Canada (CIC). 2005. Facts and Figures Immigration Overview: Permanent and Temporary Residents. Ottawa: CIC.

Crompton, S. and M. Vickers. 2000. "One Hundred Years of Labour Force," Canadian Social Trends 57: 2-13.

De Silva, A. 1997. "Earnings of Immigrant Classes in the Early 1980s: A Reexamination," Canadian Public Policy/Analyse de Politiques 23(2): 179-202. 
DeVoretz, D., S. Pivnenko, and M. Beiser. 2004. The Economic Experiences of Refugees in Canada. IZA Discussion Paper, No. 1088. Retrieved December 22, 2008 (papers.ssrn.com/sol3/papers.cfm?abstract_id=526022).

Drucker, P. 1993. Post-Capitalist Society. New York: Harper.

Duleep, H. O. and M. C. Regets. 1996. “Admission Criteria and Immigrant Earning Profiles,” International Migration Review 30(2): 571-590.

Frenette, M. and R. Morissette. 2003. Will They Ever Converge? Earnings of Immigrants and Canadian-Born Workers over the Past Two Decades. Analytical Studies Branch Research Paper Series, Cat. No. 11F0019MIE2003-215. Ottawa: Statistics Canada.

Galarneau, D. and R. Morissette. 2005. "Immigrants: Settling for Less?” Perspectives, Cat. No. 75-001-XIE. Ottawa: Statistics Canada.

Green, A. G. and D. A. Green. 1999. "The Economic Goals of Canada's Immigration Policy: Past and Present," Canadian Public Policy/Analyse de Politiques 25(4): 425-451.

Harper, S. 2008. Prime Minister Urges Stronger Trade Relations with India. Ottawa, ON: Office of the Prime Minister, April 17. Retrieved December 23, 2008 (pm.gc.ca/eng/media.asp?id=2078)

Hawkins, F. 1972. Canada and Immigration: Public Policy and Public Concern. Montreal: McGill-Queen's University Press.

Hiebert, D. 2006. Beyond the Polemics: The Economic Outcomes of Canadian Immigration. Vancouver Centre of Excellence Working Paper Series, No. 06-15. Vancouver: Metropolis.

Jasso, G. and M. R. Rosenzweig. 1995. "Do Immigrants Screened for Skills do Better Than Family Reunification Immigrants?” International Migration Review 29(1): 85-111.

Krahn, H. and G. S. Lowe. 1998. Work, Industry, and Canadian Society, 3rd edition. Toronto: Nelson.

Li, P. S. 2003. "Initial Earnings and Catch-up Capacity of Immigrants," Canadian Public Policy/ Analyse de Politiques 29(3): 319-327.

Manpower and Immigration. 1974a. Immigration and Population Statistics, Cat. No. MP23-37-1974-3. Ottawa: Manpower and Immigration.

Manpower and Immigration. 1974b. The Immigration Program, Cat. No. MP23-371974-2. Ottawa: Manpower and Immigration. 
Marr, B. and P. Siklos. 1999. "Immigrant Class and the Use of Unemployment Insurance by Recent Immigrants in Canada: Evidence from a New Data Base 1980-1995," International Migration Review 33(3): 561-593.

McCullagh, P. and J. A. Nelder. 1989. Generalized Linear Models. London: Chapman and Hall.

McDonald, J. T. and C. Worswick. 1998. "The Earnings of Immigrant Men in Canada: Job Tenure, Cohort, and Macroeconomic Conditions," Industrial and Labor Relations Review 51(3): 465-482.

McDonald, J. T. and C. Worswick. 1997. "Unemployment Incidence of Immigrant Men in Canada," Canadian Public Policy/Analyse de Politiques 23(4): 353-373.

Mukoyama, T. and A. Sahin. 2006. "Costs of Business Cycles for Unskilled Workers," Journal of Monetary Economics 53(8): 2179-2193.

Picot, G., F. Hou and S. Coulombe. 2007. Chronic Low Income and Low-income Dynamics Among Recent Immigrants. Analytical Studies Branch Research Paper Series, Cat. No. 11F0019MIE-No. 262. Ottawa: Statistics Canada.

Picot, G. and A. Sweetman. 2005. The Deteriorating Economic Welfare of Immigrants and Possible Causes: Update 2005. Analytical Studies Branch Research Paper Series, Cat. No. 11F0019MIE-No. 294. Ottawa: Statistics Canada.

Pilat, D. A. Cimper, K. Olsen and C. Webb. 2006. The Changing Nature of Manufacturing in OECD Economies. STI Working Paper 2006/9. Paris: OECD Directorate for Science, Technology and Industry.

Reitz, J. G. 2001. "Immigrant Skill Utilization in the Canadian Labour Market: Implications for Human Capital Research," Journal of International Migration and Integration 2(3): 347-378.

Reitz, Jeffrey G. 1998. Warmth of the Welcome: The Social Causes of Economic Success for Immigrants in Different Nations and Cities. Boulder, CO: Westview Press.

Stehr, N. 1994. Knowledge Societies. Thousand Oaks, CA: Sage.

Wanner, R. A. 2003. "Entry Class and the Earnings Attainment of Immigrants to Canada, 1980-1995," Canadian Public Policy/Analyse de Politiques 24(1): 53-69.

Waslander, B. 2003. "The Falling Earnings of New Immigrant Men in Canada's Largest Cities," in Canadian Immigration Policy for the $21^{\text {st }}$ Century, ed. C.M. Beach, A.G. Green, and J.G. Reitz. Kingston: John Deutsch Institute for the Study of Economic Policy, pp. 335-372. 
Worswick, C. 2003. "Immigrants' Declining Earnings: Reasons and Remedies," C.D. Howe Institute, Backgrounder 81: 1-9.

Wright, R. E. and P.S. Maxim. 1993. "Immigration Policy and Immigrant Quality," Journal of Population Economics 6(4): 337-352.

Zhou, M. 1997. "Segmented Assimilation: Issues, Controversies, and Recent Research on the New Second Generation." International Migration Review 31(4): 975-1008. 